\title{
Red Fox Vulpes vulpes (L., 1758) as a Bioindicator of Mercury Contamination in Terrestrial Ecosystems of North-Western Poland
}

\author{
Elzbieta Kalisinska • Piotr Lisowski • \\ Danuta Izabela Kosik-Bogacka
}

Received: 29 April 2011 / Accepted: 16 August 2011 / Published online: 3 September 2011

(C) The Author(s) 2011. This article is published with open access at Springerlink.com

\begin{abstract}
In this study, we determined the concentrations of total mercury $(\mathrm{Hg})$ in samples of liver, kidney and skeletal muscle of 27 red foxes Vulpes vulpes (L., 1758) from northwestern Poland, and examined the morphometric characteristics of the collected specimens. The analysis also included the relationship between $\mathrm{Hg}$ concentration and the fox size, and the suitability of individual organs as bioindicators in indirect evaluation of environmental mercury contamination. Determination of $\mathrm{Hg}$ concentration was performed by atomic absorption spectroscopy. In the analysed samples, the $\mathrm{Hg}$ concentration was low and the maximum value did not exceed $0.85 \mathrm{mgHg} / \mathrm{kg}$ dry weight $(\mathrm{dw})$. There were no significant differences in $\mathrm{Hg}$ concentrations in the analysed material between males and females or between immature and adult groups. The median concentrations of $\mathrm{Hg}$ in the liver, kidney and skeletal muscle were $0.22,0.11$ and $0.05 \mathrm{mgHg} / \mathrm{kg} \mathrm{dw}$, respectively. The correlation coefficients were significant between the concentrations of mercury in the liver, kidney and skeletal muscle (positive) and between the kidney $\mathrm{Hg}$ concentration and kidney mass (negative). Taking into account our results and findings of other authors, it may be argued that the red fox exhibits a measurable
\end{abstract}

Communicated by D. I. Kosik-Bogacka

E. Kalisinska • D. I. Kosik-Bogacka $(\bowtie)$

Department of Biology and Medical Parasitology,

Pomeranian Medical University,

Powstancow Wielkopolskich Av. 72,

70-111 Szczecin, Poland

e-mail: kodan@sci.pam.szczecin.pl

P. Lisowski

Department of Zoology and Agriculture,

West Pomeranian University of Technology,

Doktora Judyma St. 20,

71-466 Szczecin, Poland response to mercury environmental pollution and meets the requirements of a bioindicator.

Keywords Red fox · Mercury · Liver - Kidney · Muscle . Biomonitoring

\section{Introduction}

Mercury is one of the most toxic trace metals. This element is used in many industries, including pharmaceutical and chloralkali manufacturing industries, electrical engineering, mining, metallurgy and agriculture. Annually, anthropogenic pollution reaches approximately 2,300 tonnes of this metal, most of which comes from burning coal, milling of nonferrous metals and gold mining by amalgamation [1-4]. In Europe, the majority of mercury emitted into the environment comes from the combustion of solid fuels, mainly coal ( 47\%), cement production $(\sim 13 \%)$, iron milling $(\sim 5 \%)$, zinc and lead milling $(\sim 7 \%)$ and incineration of waste $(\sim 5 \%)$ [5].

In Poland, mercury emission to the atmosphere has significantly decreased in recent years, for example in 2001, 2005 and 2007 it was about 23, 21 and 15.9 tonnes of mercury, respectively [6]. Yet Poland is still one of the European countries that emit the largest quantities of this metal.

Terrestrial vertebrate organisms, including wild animals, absorb mercury via food, water, air and through the skin. Organic mercury is strongly absorbed from the gastrointestinal tract $(>90 \%)$ and accumulates in internal organs, mainly in the liver, kidney and also in the brain [7-9]. In contrast, elemental mercury and its inorganic compounds are very poorly absorbed in the gastrointestinal tract $(<10 \%)$, and additionally their harmful effects on warm-blooded vertebrates, including man, is much lower than methylmercury $(\mathrm{MeHg}$ ) which is widespread in the environment, especially in water ecosys- 
tems [10, 11]. Removal of mercury from mammalian organisms occurs through the digestive system (with biliary) and the urinary system $[2,8,12,13]$. Neurotoxicity of mercury in mammals, including the effect of $\mathrm{MeHg}$, has been well researched and documented [8, 9, 13-15].

The first reports on the toxic effects of mercury contamination on wild animals, including the fox (in particular foxes associated with agrocenoses), started to appear in 1950 s to 1970 s, when countries with highly industrialized agriculture were widely using organic mercury in chemicals for plant protection. Prey (e.g. rodents and passerines) and then predatory birds and mammals started to accumulate significant amounts of organic mercury by eating beans and small warm-blooded vertebrate herbivores contaminated with mercury. It was found that wild and laboratory mammals, due to the related damage in the central nervous system, particularly the cerebellum, exhibited awkward and jerky movements, walking in circles and falling down $[10,16,17]$.

At present, in inland ecosystems very high concentrations of mercury can be found in liver and kidney $(>20 \mathrm{mg} / \mathrm{kg}$ dry weight, dw), along with symptoms of sublethal and lethal mercury poisoning, mainly in piscivorous birds and mammals, the final consumers in aquatic trophic chains. In these chains, methylmercury is subject to biomagnification, confirmed by reports on mammals such as American mink Neovison vison (Schreber, 1777), river otter Lontra canadensis (Schreber, 1777) and Eurasian otter Lutra lutra (L., 1758) [13, 15, 18-20]. The bioaccumulation of mercury in vertebrates in inland aquatic ecosystems has been well documented, whereas much less is known about the impact of mercury on typical terrestrial organisms, including foxes and other canids [10, 12, 21-24].

The most widespread predator in the order Carnivora is the red fox Vulpes vulpes (L., 1758), occurring across an area of about 70 million square kilometres. It lives in almost the entire northern hemisphere, from the Arctic Circle to North Africa, Central America and the Asian steppes, with the exception of Iceland, the Arctic islands and parts of Siberia [25]. An omnivore with a very varied diet, the red fox easily accommodates to environmental conditions. The food of red foxes living in Poland consists mainly of small rodents, ungulate carcasses (about 58-60\% and 25-30\%), birds, and also invertebrates and plant parts [26]. In other areas of Europe, its diet may have different proportions. For example, as shown by Kauhala et al. [27], in coniferous forests of Finland the red fox mainly preys on rodents $(>60 \%$ of the diet), followed by birds and hares $(20 \%)$, and then invertebrates and plants $(20 \%)$.

In this study, we determine total mercury concentrations in liver, kidney and skeletal muscle of red foxes coming from north-western Poland. We analyse the relationship between the concentration of mercury and selected biomet- ric parameters, and also assess the usefulness of this species as an indirect bioindicator of mercury pollution.

\section{Materials and Methods}

Study Area

The research material was collected in 2004-2006 in northwestern Poland, in the West Pomerania province with its capital, Szczecin $\left(53^{\circ} 25^{\prime} 57^{\prime \prime} N, 1^{\circ} 33^{\prime} 19^{\prime \prime} \mathrm{E}\right)$. Most of the province's area is agricultural (38\%) and forested (35\%), and several percent of the area is covered by water (numerous lakes, rivers, including the Oder estuary with the Dąbie Lake and the Szczecin Lagoon; http://www.stat. gov.pl/cps/rde/xbcr/szczec/ASSETS_przegl_2.pdf). Areas from which the animals were obtained were about $10-20 \mathrm{~km}$ away from the centre of Szczecin.

In 2007, the total atmospheric emission of mercury in Poland was $15,880 \mathrm{~kg}$. In the West Pomeranian Vovoideship, it was $515 \mathrm{~kg}$, i.e. $3.2 \%$ of the Polish emission [6]. This administrative region has a moderate (II on the five-grade scale) degree of atmospheric emission of mercury. In Poland geochemical background for mercury is $<0.05 \mathrm{mg} / \mathrm{kg} \mathrm{dw}$. In years 1995-2005 in north-western Poland, the mean arithmetic concentration of this metal in river and lake sediments was 0.372 and $0.142 \mathrm{mg} / \mathrm{kg}$, respectively; therefore, it exceeded the level of the geochemical background [28]. In Poland, the average $\mathrm{Hg}$ concentration in soil estimated in 2003 was $0.036 \mathrm{mg} / \mathrm{kg} \mathrm{dw}$ [29].

The analysis of the effect of environmental factors on metal concentrations in carnivores should take into account their prey. The fox diet in Poland is dominated by food of animal origin, up to $>95 \%$ of eaten biomass; the share of rodents (mainly Microtus), dead animals (mostly ungulates) and birds are 59\%, 27\% and 9\%, respectively [30]. Mercury concentrations are low in the bodies of hunted ungulates that are not associated with aquatic trophic chains. Falandysz and Szajek [31] detected only low mercury concentrations in the muscles of deer, roe-deer and wild boar near the city of Koszalin (eastern part of the West Pomeranian voivodeship) $0.014,0.007$ and $0.023 \mathrm{mg} / \mathrm{kg}$ $\mathrm{dw}$, respectively. Many times higher concentrations of mercury were found in the muscles of ducks from northwestern Poland. Depending on their diet, it was 0.114 and $2.347 \mathrm{mg} / \mathrm{kg} \mathrm{dw}$, respectively, for in the omnivorous mallard Anas platyrhynchos (L., 1758) and piscivorous goosander Mergus merganser (L., 1758) [32, 33].

Biometrics and Sampling

Among the 27 red foxes Vulpes vulpes (L., 1758) collected for testing, most were hunted (18) but some dead specimens 
(9) were collected from roads, mostly within the Szczecin city limits. During post-mortem examination, the sex of foxes was identified on the basis of observed gonads. Age classification into adult and immature specimens was based on linear measurements of prepared skulls [34], and in some specimens on annual growth layers in fangs $[35,36]$. Individuals younger than 10 months were termed immature, while those older than 1 year were classified as adult. The adult group included 7 males and 4 females, and the immature group had 14 males and 2 females.

All foxes were weighed and measured (precision of measurements is given in parentheses). The measurements included the weights of the body (including skin, precision to $100 \mathrm{~g})$, liver and kidney $(0.1 \mathrm{~g})$ and the lengths of the body (from the nasolabial plate to the tail, $1 \mathrm{~cm}$ ), left foot $(1 \mathrm{~mm})$ and the height of the left ear $(1 \mathrm{~mm})$. In addition, we also calculated the relative weight of both liver and kidney, as the percentage of body weight.

For chemical analysis, from each individual we collected pieces of liver, thigh muscle and kidney (left or right) - a total of 81 samples, each weighing at least $0.1 \mathrm{~g}$. Within 50-60 days the samples were dried to constant weight at $50^{\circ} \mathrm{C}$. This allowed determination of the percentage of water content by gravimetric method. Then the dried material was ground in a monoplanetary Pulverisette mill. This procedure was consistent with that used by other researchers [24].

\section{Determination of Total Mercury}

The accuracy and precision of the analytical procedure was maintained by the determination of $\mathrm{Hg}$ concentration in two certified biological materials: lyophilized bovine liver (BCR 185;0.04 mg/kg dw) and lyophilized porcine kidney (BCR 186; $1.73 \mathrm{mg} / \mathrm{kg} \mathrm{dw}$; Commission of European Communities, Community Bureau of References-BCR). The percentage of recovery was $99.3 \%$ and $88 \%$, respectively.

The concentration of total $\mathrm{Hg}$ was determined by atomic absorption spectroscopy, using an AMA 254 mercury analyzer (Altec, Czech Republic). This device does not require prior digestion of the wet sample, as a dry sample is placed directly in a nickel nacelle. The detector in the AMA 254 analyzer is a silicon UV diode operating at $254 \mathrm{~nm}$, in a system of two measuring cells. The samples were analysed at specified parameters of the cycle: 60/160/60, which means the time of drying (in seconds), time of decomposition (at $550^{\circ} \mathrm{C}$ ) and waiting time for the measurement. The mercury detection limit for this device is about $0.01 \mathrm{ng}$. For each sample, two or three repetitions were performed, and the averaged result was presented as the concentrations in milligrammes per kilogramme of dry weight $(\mathrm{mg} / \mathrm{kg} \mathrm{dw})$.

\section{Statistical Analysis}

Percentage water content was calculated in the analysed samples of biological material. Arithmetic mean and standard deviation $(\mathrm{AM} \pm \mathrm{SD})$ were established for the sizes of animals and their organs. For body and organ sizes, the $\mathrm{AM} \pm \mathrm{SD}$ were calculated. In order to compare morphological parameters between age groups and sexes, a Student $t$ test was used. Pearson correlation coefficients were calculated in order to investigate possible correlations between the weights of the body, liver and kidney.

Median (Med), $\mathrm{AM} \pm \mathrm{SD}$ and percentage coefficient of variation were calculated for $\mathrm{Hg}$ concentrations in the liver, kidney and muscle. In order to determine compliance with the expected normal distribution of results, Shapiro-Wilk test was used $(p<0.05)$ for raw data and data subjected to logarithmic transformation $(\log 10)$. In order to analyse related differences between $\mathrm{Hg}$ concentrations in the tissues (liver, kidney, muscle), a Kruskal-Wallis test was applied $(p<0.05)$; for age and sex comparisons of $\mathrm{Hg}$ levels in analogical tissues, a Mann-Whitney $U$ test was used. The strengths of relationships between $\mathrm{Hg}$ concentrations in the examined biological materials were estimated using a Spearman's correlation coefficient $\left(r_{\mathrm{S}}, p<0.05\right.$ and $p<0.001$ ), while a Pearson's correlation coefficient was calculated for relationships between organ weight and $\mathrm{Hg}$ level. Statistical analysis was performed using Statistica 8.0 software.

\section{Results}

\section{Fox Morphometry}

Fox body weights ranged from 2,700 to $8,600 \mathrm{~g}$ (Table 1). Immature specimens weighed approximately $1,000 \mathrm{~g}$ less than adults, and females about $700 \mathrm{~g}$ less than males, however, these differences were not statistically significant $(p>0.05)$. Foot length in males was about $8 \mathrm{~mm}$ longer than in females $(p<0.01)$. Immature differed from adult in the weight of liver and kidney $(p<0.05)$; they were smaller by $24 \%$ and about $17 \%$, respectively. Liver weight was about $140 \mathrm{~g}$ on average and weighed 4.5 times more than the kidney. The relative weights of liver and kidney did not differ between females and males and between immature and adult. These organs in the whole group accounted for $2.6 \%$ and $0.6 \%$ of body weight.

\section{The Concentration of Mercury in Biological Samples}

In samples from the examined 27 foxes, the average percentage of water content in the liver, kidney and skeletal muscle of the fox was $70.1 \%, 72.5 \%$ and $73.3 \%$, 
Table 1 The body dimensions as well as organ relative weights of the red fox from north-western Poland

Age or sex group, the number of individuals in each group

(n) and parameters

\begin{tabular}{llll}
\multicolumn{2}{l}{ Body dimensions } \\
\hline $\begin{array}{l}\text { Weight, BW } \\
(\mathrm{g})\end{array}$ & $\begin{array}{l}\text { Length } \\
(\mathrm{cm})\end{array}$ & $\begin{array}{l}\text { Foot length } \\
(\mathrm{mm})\end{array}$ & $\begin{array}{l}\text { Ear height } \\
(\mathrm{mm})\end{array}$
\end{tabular}

Organ dimensions

\begin{tabular}{|c|c|c|c|c|c|c|c|c|c|}
\hline \multirow{2}{*}{\multicolumn{2}{|c|}{ 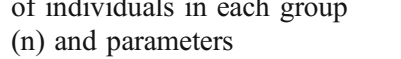 }} & \multirow{3}{*}{$\begin{array}{l}\text { Weight, BW } \\
(\mathrm{g})\end{array}$} & \multirow{3}{*}{$\begin{array}{l}\text { Length } \\
\text { (cm) }\end{array}$} & \multirow{3}{*}{$\begin{array}{l}\text { Foot length } \\
(\mathrm{mm})\end{array}$} & \multirow{3}{*}{$\begin{array}{l}\text { Ear height } \\
(\mathrm{mm})\end{array}$} & \multirow{2}{*}{\multicolumn{2}{|c|}{ Absolute (g) }} & \multirow{2}{*}{\multicolumn{2}{|c|}{ Relative (\%) }} \\
\hline & & & & & & & & & \\
\hline & & & & & & Liver (L) & Kidney $(\mathrm{K})$ & $\mathrm{L} / \mathrm{BW}$ & $\mathrm{K} / \mathrm{BW}$ \\
\hline \multirow{2}{*}{$\operatorname{im}(n=16)$} & $\mathrm{AM} \pm \mathrm{SD}$ & $5,387 \pm 924$ & $65 \pm 7$ & $158 \pm 7$ & $84 \pm 8$ & $131 \pm 35^{*}$ & $30 \pm 6^{*}$ & $2.5 \pm 0.6$ & $0.6 \pm 0.1$ \\
\hline & Min-max & $3,700-7,200$ & $50-76$ & $148-170$ & $71-100$ & $71-210$ & $22-42$ & $1.3-3.8$ & $0.4-0.7$ \\
\hline \multirow[t]{2}{*}{ ad $(n=11)$} & $\mathrm{AM} \pm \mathrm{SD}$ & $6,018 \pm 1,126$ & $68 \pm 5$ & $158 \pm 7$ & $85 \pm 9$ & $162 \pm 32 *$ & $35 \pm 5^{*}$ & $2.8 \pm 0.7$ & $0.6 \pm 0.1$ \\
\hline & Min-max & $4,900-8,600$ & $61-78$ & $150-175$ & $72-100$ & $115-204$ & $25-43$ & $1.6-3.6$ & $0.5 \pm 0.7$ \\
\hline \multirow[t]{2}{*}{$\mathrm{M}(n=21)$} & $\mathrm{AM} \pm \mathrm{SD}$ & $5,800 \pm 1,123$ & $67 \pm 7$ & $160 \pm 6^{* *}$ & $86 \pm 8$ & $145 \pm 36$ & $33 \pm 6$ & $2.6 \pm 0.7$ & $0.6 \pm 0.1$ \\
\hline & Min-max & $3,700-8,600$ & $50-78$ & $148-175$ & $71-100$ & $71-210$ & $24-43$ & $1.3-1.8$ & $0.4-0.7$ \\
\hline \multirow[t]{2}{*}{$\mathrm{F}(n=6)$} & $\mathrm{AM} \pm \mathrm{SD}$ & $5,100 \pm 335$ & $65 \pm 2$ & $152 \pm 3 * *$ & $81 \pm 6$ & $140 \pm 40$ & $29 \pm 6$ & $2.7 \pm 0.7$ & $0.6 \pm 0.1$ \\
\hline & Min-max & $4,700-5,600$ & $61-67$ & $150-155$ & $72-90$ & $102-204$ & $22-36$ & $2.1-3.6$ & $0.4-0.7$ \\
\hline \multirow[t]{2}{*}{ Total $(n=27)$} & $\mathrm{AM} \pm \mathrm{SD}$ & $5,644 \pm 1,039$ & $66 \pm 6$ & $158 \pm 7$ & $85 \pm 8$ & $144 \pm 37$ & $32 \pm 6$ & $2.6 \pm 0.7$ & $0.6 \pm 0.1$ \\
\hline & Min-max & $3,700-8,600$ & $50-78$ & $148-175$ & $71-100$ & $71-210$ & $22-43$ & $0.7-1.2$ & $0.4-0.7$ \\
\hline
\end{tabular}

im immature, ad adult, $M$ male, $F$ female, $A M$ arithmetic mean, $S D$ standard deviation

${ }^{*} p<0.05$ statistical difference; $* * p<0.01$ statistical difference

respectively. Data on mercury concentrations in liver, kidney and muscle of the fox age groups and gender are shown in Table 2. The distribution of empirical data on mercury concentrations in the liver, kidney and skeletal muscle diverged from the expected normal distribution, as shown by the Shapiro-Wilk test $(p<0.05)$. After logarithmic transformation ( $\log 10)$, hepatic and nephric $\mathrm{Hg}$ concentration distributions were consistent with the expected normal distribution (Shapiro-Wilk test, $p>0.05$ ), but the muscle concentration distribution still differed from

Table 2 Total of mercury concentration in the liver, kidney and skeletal muscle (milligrammes per kilogramme dry weight) in the red fox from north-western Poland

\begin{tabular}{|c|c|c|c|c|}
\hline \multicolumn{2}{|c|}{$\begin{array}{l}\text { Age or sex group, the number of individuals } \\
\text { in each group (n) and parameters }\end{array}$} & \multirow{2}{*}{$\begin{array}{l}\text { Liver } \\
0.10\end{array}$} & \multirow{2}{*}{$\begin{array}{l}\text { Kidney } \\
0.26\end{array}$} & \multirow{2}{*}{$\begin{array}{l}\text { Muscle } \\
0.05\end{array}$} \\
\hline $\operatorname{im}(n=16)$ & Med & & & \\
\hline & $\mathrm{Q}_{\mathrm{L}}-\mathrm{Q}_{\mathrm{U}}$ & $0.08-0.17$ & $0.19-0.37$ & $0.03-0.07$ \\
\hline & $\mathrm{AM} \pm \mathrm{SD}$ & $0.13 \pm 0.09$ & $0.33 \pm 0.21$ & $0.06 \pm 0.04$ \\
\hline & Min-max & $0.04-0.37$ & $0.09-0.81$ & $0.02-0.19$ \\
\hline \multirow[t]{4}{*}{ ad $(n=11)$} & Med & 0.11 & 0.20 & 0.05 \\
\hline & $\mathrm{Q}_{\mathrm{L}}-\mathrm{Q}_{\mathrm{U}}$ & $0.08-0.16$ & $0.15-0.28$ & $0.04-0.06$ \\
\hline & $\mathrm{AM} \pm \mathrm{SD}$ & $0.15 \pm 0.13$ & $0.27 \pm 0.20$ & $0.08 \pm 0.06$ \\
\hline & Min-max & $0.08-0.52$ & $0.14-0.84$ & $0.03-0.23$ \\
\hline \multirow[t]{4}{*}{$\mathrm{M}(n=21)$} & Med & 0.11 & 0.22 & 0.05 \\
\hline & $\mathrm{Q}_{\mathrm{L}}-\mathrm{Q}_{\mathrm{U}}$ & $0.08-0.16$ & $0.18-0.35$ & $0.04-0.06$ \\
\hline & $\mathrm{AM} \pm \mathrm{SD}$ & $0.14 \pm 0.08$ & $0.30 \pm 0.19$ & $0.06 \pm 0.04$ \\
\hline & Min-max & $0.04-0.37$ & $0.09-0.81$ & $0.03-0.19$ \\
\hline \multirow[t]{4}{*}{$\mathrm{F}(n=6)$} & Med & 0.10 & 0.22 & 0.05 \\
\hline & $\mathrm{Q}_{\mathrm{L}}-\mathrm{Q}_{\mathrm{U}}$ & $0.07-0.12$ & $0.16-0.28$ & $0.03-0.05$ \\
\hline & $\mathrm{AM} \pm \mathrm{SD}$ & $0.16 \pm 0.18$ & $0.31 \pm 0.26$ & $0.07 \pm 0.08$ \\
\hline & Min-max & $0.05-0.52$ & $0.14-0.84$ & $0.02-0.23$ \\
\hline \multirow[t]{4}{*}{ Total $(n=27)$} & Med & 0.11 & 0.22 & 0.05 \\
\hline & $\mathrm{Q}_{\mathrm{L}}-\mathrm{Q}_{\mathrm{U}}$ & $0.08-0.16$ & $0.16-0.35$ & $0.04-0.06$ \\
\hline & $\mathrm{AM} \pm \mathrm{SD}$ & $0.14 \pm 0.10$ & $0.30 \pm 0.21$ & $0.07 \pm 0.05$ \\
\hline & Min-max & $0.04-0.52$ & $0.09-0.84$ & $0.02-0.24$ \\
\hline
\end{tabular}

im immature, ad adult, $M$ male, $F$ female, $M e d$ median, $Q_{L}$ lower, $Q_{U}$ upper quartile, $A M$ arithmetic mean, $S D$ standard deviation 
one another (Shapiro-Wilk, $p<0.05$ ). Median concentrations (Med) of $\mathrm{Hg}$ in the liver, kidney and skeletal muscle were small and generally did not exceed $0.30 \mathrm{mg} / \mathrm{kg} \mathrm{dw}$. The highest concentrations of $\mathrm{Hg}$ were recorded in the kidney and the smallest in the skeletal muscle $(0.84$ and $0.02 \mathrm{mg} / \mathrm{kg} \mathrm{dw}$, respectively). Therefore, median values of $\mathrm{Hg}$ concentrations can be arranged in the following series: kidney $>$ liver $>$ skeletal muscle, with the ratio of $4: 2: 1$. This observation concerned all the groups (Mann-Whitney $U$ test, $p<0.05$ ). The Kruskal-Wallis test showed a difference in $\mathrm{Hg}$ concentrations between skeletal muscle and liver $(p<0.01)$, skeletal muscle and kidney $(p<0.0001)$ and between the Hg concentrations in liver and kidney $(p<0.01)$. Comparison of $\mathrm{Hg}$ concentrations in with regard to age (immature and adult) and sex (female and male) showed no statistically significant differences (Mann-Whitney $U$ test, $p>0.05$ ).

Analysis of Spearman correlation coefficients $\left(r_{\mathrm{S}}\right)$ showed that the strongest relationship existed between $\mathrm{Hg}$-liver and $\mathrm{Hg}$-skeletal muscle $\left(r_{\mathrm{S}}=0.74 ; p<0.001\right)$, and weaker relationships existed between Hg-kidney and $\mathrm{Hg}$ liver $\left(r_{\mathrm{S}}=0.60 ; p<0.001\right)$, and between Hg-kidney and Hgskeletal muscle $\left(r_{\mathrm{S}}=0.57 ; p<0.01\right)$. The relationship between the mass of kidney and $\mathrm{Hg}$ concentration was negative and statistically significant $(r=-0.50 ; p<0.02)$. This correlation coefficient suggests that the increasing concentration of nephric $\mathrm{Hg}$ is accompanied by a lower mass of kidney.

\section{Discussion}

Ecotoxicological studies on the prevalence of toxic metals and other xenobiotics in the terrestrial environment include the measurements of their concentrations in the tissues of birds and mammals. Among mammals, primarily herbivorous ungulates are deemed good indicators of pollution: fallow deer Dama dama (L., 1758), red deer Cervus elaphus (L., 1758), moose Alces alces (L., 1758) and the omnivorous wild boar Sus scrofa (L., 1758), but they are not represented outside their natural habitats and areas of incidence [37-41]. Furthermore, the home ranges of the individuals of those species are very large, which hinders the determination of sources of pollution [42]. In contrast to the aforementioned ungulates, the fox easily adapts to a wide range of environments, including urban areas, and occupies small territories with an average home range of $0.5 \mathrm{~km}^{2}$ [25].

Although there were some reports of red foxes that were ten or so years old, their average lifespan is much shorter $[25,43,44]$. It is estimated that most foxes die in the first months and years of their lives, as reflected in the age structure of specimens collected for this study, where out of
27 foxes, $16(\sim 60 \%)$ were classified as immature. The average body and kidney weights in foxes from NW Poland did not deviate from those observed in an Italian population examined by Cavallini [45], although what differed was the average weight of livers, which was $12 \%$ higher. Cavallini [45] points out that data on the morphometry of the freeliving red fox, i.e. on the body (except for weight and length) and internal organs including the liver and kidney, are rarely published in Europe and other parts of the world, so our data may be deemed complementary in this regard.

In mammals, mercury is determined mostly in the liver and kidney which perform detoxification functions. Although there are already a few reports on mercury in red fox, there has not been established the mercury threshold value for this mammal (above which adverse changes occur). Such information is available for the domestic dog Canis lupus familiaris L. 1758 which also belongs to the family Canidae. The laboratory tests conducted on the dog show that the typical concentration of mercury (reflecting the geochemical background) in the liver and kidney is $<0.1 \mathrm{mg} / \mathrm{kg}$ wet weight, ww $(\sim 0.3 \mathrm{mg} / \mathrm{kg} \mathrm{dw})$, while 2.8 and $3.3 \mathrm{mgHg} / \mathrm{kg}$ ww are considered lethal (9.3 and $11 \mathrm{mgHg} / \mathrm{kg} \mathrm{dw}$ ) [46]. In general, dogs usually have small amounts of mercury in their livers and kidneys, for example dogs studied in Spain had 0.032 and $0.053 \mathrm{mg} / \mathrm{kg}$ ww, respectively and it was proved that higher amounts of mercury were accumulating in kidney (but not the liver) of dogs from urban areas than from rural areas [47]. Bilandzic et al. [48] well documented an influence of suburban and rural habitats on mercury accumulation in Croatian red foxes. They found higher levels of hepatic and nephric mercury concentrations in suburban red foxes than in rural areas.

The accumulation of considerable amounts of mercury in canines depends very much on their diet, especially when it is rich in fish, as documented in several cases [24, 49]. However, mercury poisoning in this group of wild mammals is very rare. One known case was observed in a Swedish wild fox with $\mathrm{Hg}$ poisoning symptoms - running around, staggering, apparently blind without olfactory sense. A mixed sample from the liver and kidney from that individual contained $30 \mathrm{mg} \mathrm{Hg} / \mathrm{kg}$ ww [16]. Later, starting from the 1980s, neither red fox nor Arctic fox Vulpes lagopus (L., 1758) were observed to have nephric and hepatic $\mathrm{Hg}$ concentrations higher than $10 \mathrm{mg} / \mathrm{kg}$ dw, which corresponds to $\sim 2.5 \mathrm{mgHg} / \mathrm{kg}$ ww (Table 3).

In recent years, the highest $\mathrm{Hg}$ concentrations in the liver and kidney of the red fox ranged from about 4.2 to $5.4 \mathrm{mgHg} / \mathrm{kg} \mathrm{dw}$ and were observed only in single individuals in Poland and Spain (Table 3). In both cases, the considerable $\mathrm{Hg}$ concentrations were due to unusual environmental conditions and diet. The red foxes on the small island of Mielin in Poland (West Pomerania the Oder 


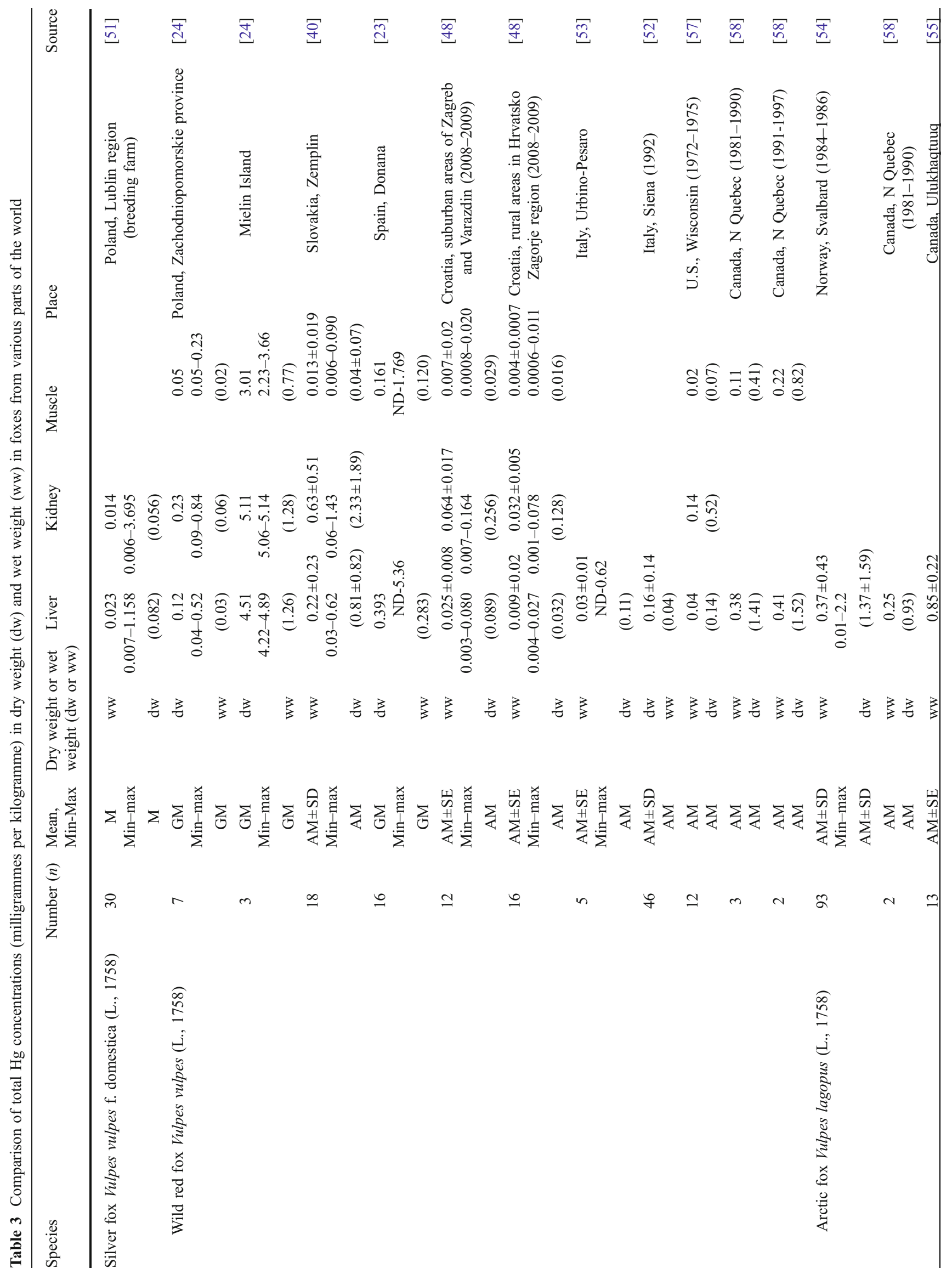


estuary), mainly fed on fish and dead cormorant chicks Palacrocorax carbo (L., 1758), which very strongly connected them with the aqueous food chain [24]. Spanish red foxes in the Donana National Park ate food (mainly rodents) contaminated with heavy metals, including mercury, because the area had been flooded by water from mines $[23,50]$.

In the examined foxes from north-western Poland, the median concentrations of $\mathrm{Hg}$ in the kidney, liver and muscle were low $(0.22,0.11$ and $0.05 \mathrm{mg} / \mathrm{kg} \mathrm{dw}$, respectively) and very close to values determined in foxes $(n=7)$ in the same area [24] (Table 3). With respect to kidney and liver it can be considered that these values reflect the geochemical background, as suggested by Farrar et al. [46]. However, when compared with the nephric and hepatic Hg concentrations given by Cybulski et al. [51] for the farmed silver fox ( $V$. vulpes f. domestica; 0.056 and $0.082 \mathrm{mg} / \mathrm{kg} \mathrm{dw}$, respectively), red foxes in this study had about $290 \%$ higher concentrations of mercury in the kidney and 30\% higher in liver. Also in the liver of red foxes from other European countries (Spain, Italy, Croatia and Slovakia), mercury concentrations were higher than in the silver fox, which is probably related to differences in diets of domesticated and wild specimens of this species and the degree of $\mathrm{Hg}$ environmental pollution. Similar values to the average $\mathrm{Hg}$ concentration in the liver of the fox in north-western Poland are reported for a population inhabiting Italy $[52,53]$ and suburban areas in Croatia [48]. In Slovakia, in studies on foxes living in areas with significant heavy metal contamination, nephric and hepatic $\mathrm{Hg}$ concentrations in the red fox were $\sim 6-9$ times higher than in foxes of the northwestern Poland in this study, while concentrations of mercury in the muscles of both populations were similar (Table 3).

Some works on mercury in canids include analyses of age- and sex-related differences in the $\mathrm{Hg}$ concentrations. In farmed red foxes from Poland, wild red foxes from Poland and Spain, the Arctic fox from Norway and the dog in Spain, there were no statistically significant differences between different age groups in relation to hepatic $\mathrm{Hg}$ concentrations, and in the red fox from Poland and dog from Spain with respect to nephric $\mathrm{Hg}[23,47,51,54$, this study]. Hepatic and nephric $\mathrm{Hg}$ concentrations did not differ between males and females of the Polish red fox and Spanish dog [47, this study]. However, Millan et al. [23] noted a greater concentration of $\mathrm{Hg}$ in muscles of adult foxes compared to cubs ( $<1$ month). In foxes in Poland, no differences were found in mercury content in muscles of both sexes and compared between age groups (immature and adult), but all specimens examined by us were over the age of 6 months.

In comparison with the Arctic fox (both from Norway and North America), Hg concentrations in the livers of the 
European red fox from non-contaminated or slightly polluted areas were lower, and the differences between the species may have resulted from different diets, a higher share of fish in the Arctic fox, especially in coastal areas, geological background, and the different level of $\mathrm{Hg}$ environmental pollution [54-56].

Red fox is a species with a wide geographical range, occurring for the entire year in a small home range. It has a high position in the trophic pyramid and accumulates various xenobiotics, including $\mathrm{Hg}$. Taking into account our results and findings of other authors, it may be argued that the fox exhibits a measurable response to environmental $\mathrm{Hg}$ pollution and meets the requirements for bioindicators $[23,24,42,48,52,53]$. Thanks to the collection of data on the mercury concentration in fox liver and kidney, it is possible to make comparisons not only between European countries but entire continents (e.g. Europe and North America). That is why it seems justified to research the degree of $\mathrm{Hg}$ contamination of typical inland ecosystems with the widest use of the fox as a bioindicator.

Open Access This article is distributed under the terms of the Creative Commons Attribution Noncommercial License which permits any noncommercial use, distribution, and reproduction in any medium, provided the original author(s) and source are credited.

\section{References}

1. Pacyna EG, Pacyna JM, Pirrone N (2001) European emissions of atmospheric mercury from anthropogenic sources in 1995. Atmos Environ 35:2987-2996

2. UNEP (2002) Global mercury assessment. UNEP Chemicals, Switzerland, Geneva, pp 1-270

3. AMAP/UNEP (2008) Technical background report to the global atmospheric mercury assessment. Arctic Monitoring and Assessment Programme/UNEP Chemicals Branch, pp 1-159

4. Pirrone N, Cinnirella S, Feng X, Finkelman R, Friedli HR, Leaner J, Mason R, Mukherjee AB, Stracher G, Streets DG, Telmer K (2010) Global mercury emissions to the atmosphere from anthropogenic and natural sources. Atmos Chem Phys Discuss 10:5951-5964

5. Pacyna EG, Pacyna JM, Fudala J, Strzelecka-Jastrzab E, Hlawiczka S, Panasiuk D (2006) Mercury emissions to the atmosphere from anthropogenic sources in Europe in 2000 and their scenarios until 2020. Sci Total Environ 370:147-156

6. Debski B, Olendrzynski K, Cieslinska J, Kargulewicz I, Skoskiewicz J, Olecka A, Kania K (2009) An emission inventory of SO, NO, NH, dusts, heavy metals, NMVOCs, POPs in Poland in 2007. KASHUE, Environmental Protection Insitute, Warsaw, pp 1-92, in Polish

7. Davis LE, Kornfield M, Mooney HS, Fiedler KJ, Haaland KY, Orrison WW, Cernichiari E, Clarkson TW (1994) Methylmercury poisoning: long-term clinical, radiological, toxological, and pathological studies of an affected family. Ann Neurol 35:680-688

8. Graeme KA, Pollack CV (1998) Heavy metal toxicity, part I: arsenic and mercury. J Emerg Med 16:45-56
9. Castoldi AF, Coccini T, Ceccatelli S, Manzo L (2001) Neurotoxicity and molecular effects of methylmercury. Brain Res Bull 55:197-203

10. Wolfe MF, Schwarzbach S, Sulaiman RA (1988) Effects of mercury on wildlife: a comprehensive review. Environ Toxicol Chem 17:146-160

11. Wiener JG, Krabbenhof DP, Heinz GH, Scheuhammer AM (2003) Ecotoxicology of mercury. In: Hoffman DJ, Ratnner BA, Burton GA, Cairns J (eds) Handbook of Ecotoxicology. Lewis Publishers, Boca Raton, pp 409-463

12. Eisler R (1987) Mercury hazards to fish, wildlife, and invertebrates: a synoptic review. U. S. Fish and Wildlife Service. Biol Rep 85:1-63

13. Scheuhammer AM, Meyer MW, Sandheinrich MB, Murray MW (2007) Effects of environmental methylmercury on health of wild birds, mammals, and fish. Ambio 36:12-18

14. Boening DW (2000) Ecological effects, transport, and fate of mercury: a general review. Chemosphere 40:1335-1351

15. Basu N, Head J (2010) Mammalian wildlife as complementary models in environmental neurotoxicology. Neurotoxicol Teratol $32: 114-119$

16. Borg K, Wanntorp H, Erne K, Hanko E (1969) Alkyl mercury poisoning in terrestrial Swedish wildlife. Viltrevy 6:301-379

17. Wobeser G, Nielsen NO, Schiefer B (1976) Mercury and mink. II. Experimental methyl mercury intoxication. Can J Comp Med 40:34-45

18. Yates DE, Mayack DT, Munney K, Evers DC, Major A, Kaur T, Taylor RJ (2005) Mercury levels in mink (Mustela vison) and river otter (Lontra canadensis) from northeastern North America. Ecotoxicology 14:263-274

19. Klenavic K, Champoux L, Mike O, Daoust PY, Evans RD, Evans HE (2008) Mercury concentrations in wild mink (Mustela vison) and river otters (Lontra canadensis) collected from eastern and Atlantic Canada: relationship to age and parasitism. Environ Pollut 156:359-366

20. Walker LA, Lawlor AJ, Chadwick EA, Potter E, Pereira MG, Shore RF (2010) Inorganic elements in the livers of Eurasian otters, Lutra lutra, from England and Wales in 2007 \& 2008: a Predatory Bird Monitoring Scheme (PBMS) report. Centre for Ecology \& Hydrology, Lancaster, UK, pp 1-13

21. Becker DS, Bigham GN (1995) Distribution of mercury in the aquatic food web of Onondaga Lake, New York. Water Air Soil Pollut 80:931-938

22. Gamberg M, Braune B, Davey E, Elkin B, Hoekstra PF, Kennedy D, Macdonald C, Muir D, Nirwal A, Wayland M, Zeeb B (2005) Spatial and temporal trends of contaminants in terrestrial biota from the Canadian Arctic. Sci Total Environ 351-352:148-164

23. Millan J, Mateo R, Taggart MA, Lopez-Bao JV, Viota M, Monsalve L, Camarero PR, Blazquez E, Jimenez B (2008) Levels of heavy metals and metalloids in critically endangered Iberian lynx and other wild carnivores from Southern Spain. Sci Total Environ 399:193-201

24. Kalisinska E, Lisowski P, Salicki W, Kucharska T, Kavetska K (2009) Mercury in wild terrestrial carnivorous mammals from north-western Poland and unusual fish diet of red fox. Acta Theriol 54:345-356

25. MacDonald DW, Reynolds JC (2004) Red fox Vulpes vulpes Linnaeus, 1758 (Least concern, 2004). In: Sillero-Zubiri C, Hoffmann M, Macdonald DW (eds) Canids: foxes, volves, jackals and dogs. Status survey and conservation action plan. IUCN/SSC Canid Specialist Group, Gland, Switzerland and Cambridge, UK, pp 129-136

26. Jedrzejewska B, Jedrzejewski W (1998) Predation in vertebrate communities. The Bialowieza Primeval Forest as a case study. Springer Verlag, Berlin, Heidelberg, pp 1-450

27. Kauhala K, Laukkanen P, von Rege I (1998) Summer food composition and food niche overlap of the raccoon dog, red fox and badger in Finland. Ecography 21:457-463 
28. Bojakowska I, Gliwicz T, Małecka K (2006) Results of geochemical analysis of bottom sediments in Poland (2003-2005). Environmental Monitoring Library, Warsaw, pp 1-116, in Polish

29. Debski B, Chudzicka-Popek M (2005) Evaluation of actual status selenium and mercury in Polish agro-systems. ISAH 1:95-102

30. Kidawa D, Kowalczyk R (2011) The effects of sex, age, season and habitat on diet of the red fox Vulpes vulpes in northeastern Poland. Acta Theriol 56:209-218

31. Falandysz J, Szajek L (1991) Mercury content in muscles, liver, and kidney of game animals in the northern regions of Poland. Bromatol Chem Toksykol 224:111-113, in Polish

32. Kalisińska E, Budis H, Podlasińska J, Kavetska K, Łanocha N (2010) Body condition and mercury concentration in apparently healthy goosander (Mergus merganser) wintering in the Odra estuary, Poland. Ecotoxicology 19:1382-1399

33. Kalisińska E, Lisowski P, Jackowski A (2010) Mercury in muscle of mallard Anas platyrhynchos from the vicinity of Szczecin, Poland. Oceanol Hydrobiol Stud 39(supl. 1):79-92

34. Churcher CS (1960) Cranial variation in the north American red fox. J Mammol 4:349-360

35. Harris S (1978) Age determination in the red fox (Vulpes vulpes) - an evaluation of technique efficiency as applied to a sample of suburban foxes. J Zool 184:91-117

36. Goodard HN, Reynolds JC (1993) Age determination in the red foxes (Vulpes vulpes L.) from tooth cementum lines. Gibier Faune Sauvage 10:173-187

37. Froslie A, Haugen A, Holt G, Norheim G (1986) Levels of cadmium in liver and kidneys from Norwegian cervides. Bull Environ Contam Toxicol 37:453-460

38. Doganoc DZ, Gacnik KS (1995) Lead and cadmium in meat and organs of game in Slovenia. Bull Environ Contam Toxicol 54:166-170

39. Dobrowolska A, Melosik M (2002) Mercury contents in liver and kidneys wild boar (Sus scrofa) and red deer (Cervus elaphus). Z Jagdwiss 48:156-160

40. Piskorova L, Vasilkova Z, Krupicer I (2003) Heavy metals residues in tissues of wild boar (Sus scrofa) and red fox (Vulpes vulpes) in the Central Zemplin region of the Slovak Republic. Czech J Anim Sci 48:134-138

41. Sobanska MA (2005) Wild boar hair (Sus scrofa) as a non-invasive indicator of mercury pollution. Sci Total Environ 339:81-88

42. Dip R, Stieger C, Deplazes P, Hegglin D, Müller U, Dafflon O, Koch H, Naegli H (2001) Comparison of heavy metal concentration in tissues of red foxes from adjacent urban, suburban, and rural areas. Arch Environ Contam Toxicol 40:551-556

43. Cavallini P, Santini S (1995) Age determination in the red fox in Mediterranean habitat. Z Saugetierkunde 60:136-142

44. Mulder JL (2004) Longevity records in the red fox. Lutra 47:51-52

45. Cavallini P (1997) Internal organ of the red fox Vulpes vulpes: data from the wild. Acta Theriol 42:91-98
46. Farrar WP, Edwards JF, Willard MD (1994) Pathology in a dog associated with elevated tissue mercury concentrations. J Vet Diagn Invest 6:511-514

47. Lopez-Alonso M, Miranda M, García-Partida P, Cantero F, Hernandez J, Benedito JL (2007) Use of dogs as indicators of metal exposure in rural and urban habitats in NW Spain. Sci Total Environ 372:668-675

48. Bilandzic N, Dezdek D, Sedak M, Dokic M, Solomun B, Varenina I, Knezevic Z, Slavica A (2010) Concentrations of trace elements in tissues of red fox (Vulpes vulpes) and stone marten (Martes foina) from suburban and rural areas in Croatia. Bull Environ Contam Toxicol 85:486-491

49. Hansen JC, Reske-Nielsen E, Thorlacius-Ussing O, Rungby J, Danscher G (1989) Distribution of dietary mercury in a dog. Quantitation and localization of total mercury in organs and central nervous system. Sci Total Environ 78:23-43

50. Grimalt JO, Ferrer M, Macpherson E (1999) The mine mining accident in Aznalcollar. Sci Total Environ 242:3-11

51. Cybulski W, Chalabis-Mazurek A, Jakubczak A, Jarosz L, Kostro K, Kursa K (2009) Content of lead, cadmium, and mercury in the liver and kidneys of silver foxes (Vulpes vulpes) in relation to age and reproduction disorders. Bull Vet Inst Pulawy 53:65-69

52. Corsolini S, Focardi S, Leonzio C, Lovari S, Monaci F, Romeo G (1999) Heavy metals and chlorinated hydrocarbon concentrations in the red fox in relation to some biological parameters. Environ Monit Assess 54:87-100

53. Alleva E, Francia N, Pandolfi M, De Marinis AM, Chiarotti F, Santucci D (2006) Organochlorine and heavy-metal contaminants in wild mammals and birds of Urbino-Pesaro province, Italy: an analytic overview for potential bioindicators. Arch Environ Contam Toxicol 51:123-134

54. Prestrud P, Norheim G, Sivertsen T, Daae HL (1994) Levels of toxic and essential elements in arctic fox in Svalbard. Polar Biol $14: 155-159$

55. Hoekstra PF, Braune BM, Elkin B, Armstrong FAJ, Muir DCG (2003) Concentrations of selected essential and non-essential elements in arctic fox (Alopex lagopus) and wolverines (Gulo gulo) from the Canadian Arctic. Sci Total Environ 309:81-92

56. Dehn LA, Follmann EH, Thomas DL, Sheffield GG, Rosa C, Duffy LK, O'Hara TM (2006) Trophic relationships in an Arctic food web and implications for trace metal transfer. Sci Total Environ 362:103-123

57. Sheffy TB, Amant JRS (1982) Mercury burdens in furbearers in Wisconsin. J Wildl Manag 46:1117-1120

58. Champoux L, Rodrigue J, Braune B, Leclair D (1999) Contaminants in Northern Québec wildlife. In: Jensen J (ed) Synopsis of research conducted under the 1997-1998 Northern Contaminants Program. Department of Indian Affairs and Northern Development, Ottawa, pp 109-116 